\title{
Implementation of the Mabims Criteria in Determining the Beginning of Islamic Month in Indonesia and Brunei Darussalam
}

\author{
Ahmad Wahidi1, ${ }^{1,}$, Noer Yasin², Abdul Kadir ${ }^{3}$, Abd. Rouf ${ }^{4}$, Saiful Haq ${ }^{5}$ \\ 1,2,3,4,5 Universitas Islam Negeri Maulana Malik Ibrahim Malang, Indonesia \\ *Corresponding author. Email: wahidi@syariah.uin-malang.ac.id
}

\begin{abstract}
The emergence of criteria made by the Minister of Religion of Brunei, Indonesia, Malaysia and Singapore (MABIMS) in the determination of the beginning of the Islamic month which was the result of the meeting of the Southeast Asian ministers of religion, namely Brunei Darussalam, Indonesia, Malaysia and Singapore which was first held in 1989 in Brunei. The meeting discussed cooperation in the field of hisab ru'yat between the four countries. In Indonesia, the MABIMS criterion is better known as the hisab imkān al-ru'yah method and was discussed for the first time in 1998 in March by hisab and ru'yat experts and representatives of Islamic social organizations - such as Muhammadiyah, NU, Persis, Al- Ershad and others. The deliberation that took place on September 28, 1998 resulted in a decision on 8 criteria for MABIMS in Indonesia. However, in reality the Indonesian government is considered inconsistent with the application of the MABIMS Criteria. According to the initial assumption, Indonesian researchers sometimes prefer the use of rukyat rather than using the MABIMS criteria reckoning. Meanwhile, Brunei Darussalam was impressed with Indonesia when it applied the MABIMS criteria inconsistently, because Brunei Darussalam only applied the MABIMS Criteria reckoning in the determination of the beginning of the Islamic month apart from Ramadan, Shawwal and Dzulhijjah. This research is a normative type of research using a qualitative approach, using primary and secondary data in the study. This research resulted in: First, the two countries only apply in the months other than Ramadan, Syawal and Dzulhijjah, while the determination of the first three months of Islam uses the guidelines of rukyatul hilal. Second, in terms of the validity of the application of the MABIMS Criteria in Indonesia and Brunei Darusslam according to fiqh and astronomy, it is permissible to use the approach of observational data or rukyatul hilal in the field.
\end{abstract}

Keywords: MABIMS, Determining the Beginning of Islamic Month, Indonesia and Brunei Darussalam

\section{INTRODUCTION}

The problem of determining the beginning of the Islamic month is a classic problem that has not been resolved until now. In the era of the 70-80s, the debate on the determination of the beginning of the month only occurred in the two largest religious organizations in Indonesia, namely NU and Muhammadiyah where the differences in the determination of 1 Ramadhan, Syawal, and Dzulhijjah were usually only one day apart but now the differences in the initial determination of these months can to be more than 3 different days. This is because there are many religious schools and organizations in Indonesia that have different methods or criteria for determining the beginning of the month and each of them claims and believes their method is the most correct and under the guidance of the Qur'an and the Prophet's Hadith.

There are those who think that the difference in determining the start of the Islamic month is caused by the very rapid development of astronomy in Indonesia so that many creative and innovative astronomers can develop various methods of determining the beginning of the month, differences in determining the start of the month, differences in determining the start of the month. beginning of the month is something that is natural because each has its own method. So that there are those who think that this is not necessary, it is precisely a blessing because what makes the difference is grace.

However, when we pull this into the socio-political realm, what happens is where the sect of hisab and sect 
of ruqyat each fight for influence and want to show their domination and existence in Indonesia. There have been many attempts to compromise the two streams but to date, it has never found common ground. Even though the community has begun to mature in responding to these differences, there are still some people (especially in social networks and internet media) who are proactive and provoke unions and even do not hesitate to blaspheme and disbelieve one another. If so difference would no longer be a blessing. Therefore, efforts to unite voices in the determination of the beginning of the month must continue because even though how to unite is more beautiful and come out of differences is better.

The emergence of the criteria set by the Minister of Religion of Brunei, Indonesia, Malaysia, and Singapore (MABIMS) in the determination of the beginning of the Islamic month was the result of an informal meeting of the Southeast Asian ministers of religion, namely Brunei Darussalam, Indonesia, Malaysia and Singapore which was first held in 1989 in Brunei. The meeting discussed cooperation in various fields including hisab ru'yat between the four countries. So that a commission was formed which was given the name "Jawatan Kuasa" to accord ru'yat and taqwim Islam in the countries of Brunei Darussalam, Indonesia, Malaysia, and Singapore.[1] This commission has the task of formulating principles in compiling the Islamic calendar and cooperating in the implementation of the ru'yat. Until now, the power of attorney has produced products in the form of the Hijriyah calendar until 2020 as well as a ru'yat reckoning guide. The mixture of hisab ru'yat explains the limitations of receiving hilāl testimony, namely: High hilāl 2 degrees or more, Angle of elongation minimum 3 degrees and the age of the hilāl at sunset is at least 8 hours.

In Indonesia, the MABIMS criterion is better known as the imkān al-ru'yah hisab method and began to be discussed in 1998 in March by hisab and ru'yat experts and representatives of Islamic social organizations including Muhammadiyah, NU, Persis, Al-Irsyad and others - and only produced a decision at the deliberation on September 28, 1998. The results of the deliberation included: First, the criteria used in the preparation of the Indonesian Hijriyah Calendar were the position of the hilal which according to hisab haqiqi bi tahqiq fulfilled the ru'yat implication. Second: The criteria for ru'yat imkan is the criteria "Two-Three / Eight", namely the height of the hilal of at least 2 degrees and the distance of the angle of the sun and moon (elongation) of at least 3 degrees or the age of the moon at least 8 hours. Third, especially for the determination of the beginning of the month of Ramadan, Syawal and Zulhijah used the criteria as mentioned above and supported by empirical evidence of the sighting of the hilal. Fourth, the determination of the beginning of the month of Ramadan, Syawal, and Zulhijah is carried out in an Isbat session led by the Minister of Religion. Fifth, to realize the unity of the Indonesian Hijriyah Calendar, concrete steps need to be taken as follows: a. Forming the Work Team for Unifying the Indonesian Hijriyah Calendar. b. Reviewing a variety of developing literature involving relevant experts. c. Conducting continuous hilal observation studies. $d$. Performing the preparation of academic papers with an interdisciplinary approach. e. Organizing the Indonesian Hijriyah Calendar Conference.[2]

However, in reality, the Indonesian government is considered inconsistent with the application of the MABIMS Criteria. According to the initial assumption, Indonesian researchers sometimes prefer the use of ru'yat rather than using the MABIMS criteria reckoning. Meanwhile, Brunei Darussalam was impressed with Indonesia when it applied the MABIMS Criteria to be inconsistent. Brunei Darussalam only applies the MABIMS Criteria reckoning in the determination of the beginning of the Islamic month besides Ramadan, Shawwal, and dzulhijjah. This is what is interesting for researchers to conduct research related to the application of the MABIMS criteria in determining the Beginning of the Islamic Month in Indonesia and Brunei Darussalam.

There are various studies related to the issue of determining the beginning of the Islamic month in different focus studies, especially in the last five years. Some studies focus only on the characteristics of determining the beginning of the Islamic month in a perspective, as has been written by Faisal Yahya Yacob and Faisal Ahmad Shah,[3] this study found that the Aceh dayah group used a textual understanding of the hadith, hisab and ru'yat, and they had different opinions in the use of hisab in rejecting testimony. Regarding the concept of matla 'they acknowledge the eight degree matla' concept of Abu Makhramah, but they differ in practice. The majority of them left the concept of matla 'moving to matla'w Wilayahal-hukm for the sake of benefit, while some of them stuck to the matla theory', so they often fasted during Ramadan and had different holidays from the government. Likewise, the writings of Bustanul Iman RN,[4] which discusses the 2 methods used in determining the beginning of the Islamic month, namely (a) the rukyat method. (b) the method of reckoning. There are two methods of reckoning, namely reckoning haqîqi wujûd al-hilâl and reckoning imkân alru'yat. Second, determining the positioning of when and where the start of the day. There are three opinions: (1) The day begins at sunset (majority view); (2) The day begins at dawn (minority viewpoint), and (3) The day starts at midnight $(00.00$, is a new view). As to where the day begins there are two views: (a) Positioned $180^{\circ}$ from the city of Mecca; and (b) placed at $180^{\circ}$ from GMT. On the other hand, there are also several writings that explain the determination of the start of the month combining khilafiah in the island and sins, as written by Jayusman.[5] Meanwhile, a study conducted by Muhammad Rahma Amir,[6] talking about the formula for the beginning of the month of kamariyah in Indonesia 
This research is categorized as normative research. Normative research is included in the type of library research or document study.[7] Related to this, the researcher conducted research on scientific theories and facts contained in books or texts and manscripts related to MABIMS criteria in determining the beginning of the Islamic month. While the approach used is a qualitative approach, because the data used if the data is in the form of information distributions that do not need to be quantified.[8] According to Bogdan and Taylor, defining a qualitative approach as a research procedure that produces descriptive data in the form of words or writing.[9] The data sources in this study are divided into two parts, namely first, primary sources which are basic and must-have research materials or data, in this case the concept of determining the beginning of the Islamic month using the MABIMS criteria applied in Indonesia and Brunei Darussalam. Second, the opinions of astronomical and astronomical experts as well as scholars' from various representations of Islamic organizations in Indonesia related to the MABIMS criteria in determining the beginning of the month as supporting data for primary data.

\section{DETERMINING THE BEGINNING OF ISLAMIC MONTH}

The issue of determining the beginning of the Islamic month, especially before the months of Ramadan, Syawal and Dhulhijjah which are used by Muslims in the implementation of worship in it becomes a classic problem, it can also be polemic, actual discourse and big problem. It is called a classic problem because since the beginning of Islam, and during the development of Islam in the following decades among the companions, tabi'in, scholars and Islamic jurists have always set the three beginning of the month as the discussion in its stipulation until this moment. This issue can also be considered an actual and factual discourse because experts or experts in the discipline of rukyat, astronomers and other experts are involved in discussing and discussing the determination of the three beginning of the month and their unification efforts which are then exposed by the media freely and transparently. It is called a big problem because countries where the majority of the population are Muslim, scholars and fuqaha ', hisab-ru'yat experts and Muslim astronomers around the world study it and try to find solutions and methods of unification to this day through halaqah-halaqah which involve falak experts and world astronomy [10].

Among the factors that cause the difference in determining the beginning of the Islamic month include: First, there is a dispute of opinion in interpreting and understanding the command to start and end fasting, is it permissible to start and end fasting with rukyat alone or with ansich's calculation (hisab), and the issue of rukyat whether it is a matter of ta'abbudi or ta'aqquli. This difference ultimately triggers a dichotomy between hisab and ru'yat with the ijtihadiyah claim that ru'yat is qath'i so decisive, while hisab is dzhanniy in nature so that it is only a supporter or is ignored. On the other hand, there is a claim from ijtihadiyah which says that hisab is qath'i, therefore it is decisive, while rukyat is dzhanniy so that it is only a supporter or can be ignored.

Second, there are differences in the use of the system and calculation methods (reckoning). The method of calculating the beginning of the Islamic month in Indonesia has experienced rapid growth dynamics and has resulted in several kinds of reckoning systems / methods, the number of which is more than thirty-five (35) system calculations. Third, there are differences in the guidelines or criteria starting on the first day and the position of the moonlight at the beginning of the month.[11]

Fourth, there are differences in the method and the validity of the ru'yat report, some of the validity of the ru'yat must be in accordance with the hisab method and some do not have to comply with the hisab method, the important thing is that the person reporting the ru'yat is fair, honest, correct and is sworn in by the judge. Fifth: There are differences of opinion regarding the application of the results of rukyat to a certain area called wilayat al-hukmi or applies globally. In the rules of application in the al-hukmi wilayat there are differences of opinion on how wide the coverage of the area is whether in one country, or one city or province or one regional area, for example Southeast Asia and others. As for the application to the global area, there are differences of opinion regarding its determination to follow Saudi Arabia, on the grounds that the birth of Islam and the Ka'bah which is the direction of the Muslim community in Mecca, or is it not obliged to follow Saudi Arabia's stipulation which is important in essence wherever the new moon can be or is successful seen can be used as a guideline and basis for the entry of the beginning of the new month in the Islamic calendar.

Sixth: there are differences of opinion regarding the party entitled to determine the entry of the beginning of the Islamic month, whether it must be the government or other parties. From the several factors above, according to the author's opinion, the most impactful and considered to be the main thing is the difference in interpretation of the related texts regarding the determination of the beginning of the month which then triggers the emergence of other factors.

\section{EARLY CRITERIA FOR ISLAMIC MONTH}

There are several criteria related to determining the beginning of the month in Islam: 


\subsection{Ijtima' Criteria}

This group argues that Ijtima 'is the beginning of the change of the month without considering the position of the new moon. In the end, this group did not question whether the hilal could be made or not. This opinion is taken from the astronomical theory which says that the new moon (new moon) occurs when the sun and moon are in Ijtima '(conjunction). From this theory then classified into several opinions based on more specific criteria, including: a) Ijtima 'Qabl al-ghurub, which is the beginning of a new month or month when there is already an Ijtima' event before sunset even though the new moon is still under the ufuq or the new moon sets before the sun. Based on this situation, the Ijtima'nya occurs before the sun sets, so that the evening has entered the 1 st of the new month but if the Ijtima 'occurs after sunset then the evening is still the 30th of the month in progress; b) Ijtima 'Qabl al-Fajr is a criterion for changing the month in the Islamic calendar when the Ijtima' (conjunction) event occurs before dawn. When this happens, since dawn on that day has entered the first day of the new month. On the other hand, when Ijtima 'occurs after dawn, the morning is still on the 30th of the month which is still ongoing. This theory does not consider the position of the moon or the new moon; c) Ijtima 'Qabl Nishf al-Nahar is the criteria for changing the month in the Islamic calendar when Ijtima' (conjunction) occurs before noon. This means that if this happens then starting that day is a new moon and if the ijtima occurs after noon, then that day is still the 30th of the ongoing month; d) Ijtima' Qabl Nishf al-Layl is the criteria for changing the month in the Islamic calendar where ijtima '(conjunction) occurs before midnight. If this happens then starting that night has entered the 1st of the new month, if on the contrary, when Ijtima '(conjunction) occurs after or after midnight, that night is still the 30th of the month.

\subsection{Ijtima' and Wujud al-Hilal}

The criteria for determining the beginning of the Islamic month are provided that after the Ijtima '(conjunction) occurs, the moon sets after the setting of the sun, meaning that the young moon or new moon (there is) before the sun sets then at night it is determined as the first day of the Islamic month, regardless of angle the altitude (altitude) of the young moon or the new moon at sunset.

\subsection{Imkan al-Rukyat}

Imkan al-Rukyat is the criteria for determining the beginning of the Islamic month based on the height of the new moon which may or has been successful in rukyat. The provisions of this criterion are as follows: (a) At sunset, the altitude (altitude) of the moon above ufuq is at least $2^{\circ}$, and the angle of elongation (the curved distance) between the moon and the sun is at least $3^{\circ}$, and or, (b) At when the moon sets, the age of the moon is at least 8 hours, counted since the occurrence of Ijtima '. In Indonesia, on the evening of the first day since the occurrence of Ijtima '(i.e. every 29th of the current month), the Indonesian Government, in this case, the Ministry of Religion, through the Hisab Rukyat Agency (BHR) conducts rukyat (hilal observation) activities and is continued with the Itsbat trial, which later legally used as the basis in deciding whether that night has entered a new (calendar) month, or fulfills the current month to be 30 days. This is according to the agreement of the Minister of Religion of Brunei Darussalam, Indonesia, Malaysia, and Singapore (MABIMS), and is used officially for the determination of the beginning of the Hijri month on the Official Government Calendar. Apart from the Government's version of the Imkan al-Ru'yat method or MABIMS above, there are also other similar criteria, with different angles/minimum figures. This last criterion will be the object of this research, precisely the criteria agreed upon by the four Southeast Asian Ministers of Religion.

\section{OVERVIEW REGARDING FALAK FIQH}

Islamic Sharia has made it easy for its followers to carry out various rituals of worship and to be wasilah according to the level and context. This includes the determination of the beginning of the Islamic month as wasilah to know when to start and end the fasting of Ramadan and the time of performing wukuf at arafah for pilgrims. In this case, Islam provides the easiest and most contextual way, namely by using ru'yat al-hilal by seeing the sighting of the hilal directly, as a way to find out the end of the month of Sha'ban and the entry and end of the month of Ramadan and when the time of wukuf is to be held in Arafah.[12]

If at that time, Islam required hisab as a way of knowing and establishing the beginning of the Islamic month related to the implementation of the worship of the people, it would have been burdensome because of the context that the people in the early days of Islam did not know the science of falak or hisab at that time. In fact, astronomy at that time was better known as the science of astrology, which in society had a negative connotation because it was associated with prediction with mystical and non-logical nuances. One of the wisdoms of tasyri 'in the determination of the beginning of the month of Islam with ru'yat al-hilal according to Yusuf al-Qardawiy is a form of grace for the people so that the people at that time are not given demands that are beyond their ability to understand their mukhalafah when they are given burdens that they do not control then it is feared that they will flee from Islam and return to the religious beliefs of their ancestors [12]. 


\section{APPLICATION OF THE MABIMB CRITERIA IN INDONESIA AND BRUNEI DARUSSALAM}

\subsection{Application of the MABIMS Criteria in Indonesia}

Differences in the implementation of Ramadan fasting and holidays (Eid al-Fitr and Eid al-Adha) in Indonesia have often occurred. Although it creates a little confusion in the community, in general, with a fairly high level of community tolerance the difference is not really a problem. However, it is possible that such sensitive religious issues can cause unrest which will disturb peace if there are other factors that trigger it.

At the historical level, there were two opinions on Eid al-Adha 1421: 5 and 6 March 2001. This is due to differences in criteria among reckoning experts (astronomical calculations) and possible differences with rukyat experts (observations). Muhammadiyah with the criteria of hisab wujudul hilal (the shape of the hilal on the horizon) will definitely take up idul adha March 5, 2001. PERSIS, which includes in its almanac Eid alAdha on March 5, seems to be waiting for the government's decision, because there is no agreement on the criteria for hisab use.

NU with ru'yatul hilal decides March 5 or 6 , depending on the results of the observation on February 23. If the government (Kemenag RI) uses the criteria agreed upon with the Ministers of Religion of Brunei, Indonesia, Malaysia, and Singapore (MABIMS), it should set the Eid al-Adha on March 6. However, it turns out that the Eid al-Adha national holiday is declared March 5, which does not seem to have fully applied the criteria or applied the criteria for the form of the new moon like the other months. Another group that does not question hisab or rukyat, but the similarity of the day with Saudi Arabia, may be performing on March 5 or 6 .

On Eid al-Adha 1421 it is indeed problematic. There is no consensus among the reckoning experts. Mainly based on the entry criteria at the beginning of the month. Differences from ru'yat experts may also occur. However, in fact it is possible to find a point of contact between fellow hisab experts and and ru'yat experts. The meeting point is the criteria for imkanur or visibility of the hilal, the criteria for the possibility of hilal being ru'yat.

So far there has been no systematic research on the criteria for imkanur ru'yat based on ru'yatul hilal data in Indonesia. The criteria used by the ru'yat Research Agency of the Ministry of Religion of the Republic of Indonesia from the 1992 MABIMS III Deliberation Agreement are the criteria for as follows: the minimum height of the hilal is 2 degrees, the distance of the moon from the sun is a minimum of 3 degrees, and or the age of the moon (calculated from the time of ijtima ') at the time of the sun. set minimum 8 hours. This criterion appears to have been derived from the minimum record for observations in Indonesia on September 16, 1974. The imkanur ru'yat criterion is lower than the criteria recognized by astronomers. This is a reason for Muhammadiyah so that it is not willing to use these criteria. Currently used by Muhammadiyah is the criteria for the form of the hilal. As long as according to the results of the hilal reckoning the value is positive above the western ufuq, regardless of the height, it meets the criteria for the entry of a new moon.

According to objective reality, the government of the Republic of Indonesia through the Ministry of Religion (Kemenag) has implemented different policies in determining the start of the Hijri calendar month throughout the year. Determination of the beginning of the month for Ramadan, Shawwal, and Dzulhijjah is differentiated from other months with the consideration that in these three months there are times for carrying out rituals of worship that receive special attention, namely fasting Ramadan, Eid al-Fitr, and performing wukuf in Arafah during the Hajj. Apart from the three special months mentioned above, the determination of the beginning of the month is determined only based on the results of the reckoning (calculations) which ensure that the Moon is above the horizon at least 2 degrees after the ijtima 'event (new Moon phase - new moon) when the Sun sets in the west ufuq. Especially for Ramadan and Shawwal, the determination of the entry of the 1 st of these months is carried out through an isbat session led by the Minister of Religion which is conducted at the end of Syaban (for the determination of the beginning of Ramadan) and the end of Ramadan (for the initial determination of Shawwal) after collecting and considering the results. the results of hisab and ru'yat (observations) as well as suggestions and opinions from session participants consisting of scholars, representatives of Islamic organizations, members of the Ru'yat Hisab Agency (BHR), and representatives of friendly countries that have diplomatic relations. The criteria adopted (MoRA) and other countries that are members of the MABIMS organization (covering Brunei Darussalam, Malaysia and Singapore) so far are: • minimum height of the Moon from the horizon 20 • minimum elongation (angular distance - angular standard) between Moon and Sun 30 - Moon age (time span from conjunction to time of observation) is at least 8 hours. In fact, the above criteria are intended only for the preparation of the Hijri calendar, not to ensure that the hilal (the first observable crescent of the Moon after conjunction) can be observed. Hilal is a thin and faint object. Theoretically, only hilal with an area of $1 \%$ or more than the area of the Full Moon can be observed. For astronomers, the limit for the altitude of the new moon and the age of the Moon above has not been scientifically verified, so it is not surprising that objections arise. The criteria for the minimum height of the hilal of 2 degrees only ensures that the hilal is above the horizon and cannot be used as a basis that the hilal can definitely be observed.

The criteria for imkanur ru'yat are determined based on the success of observing the new moon. The basic 
criterion that can be used based on observations and theoretical astronomical models is the Danjon limit: the hilal is impossible to observe if the moon-sun distance is less than 7 degrees. Other criteria include those developed by Mohammad Ilyas from IICP (International Islamic Calendar Program), Malaysia. The rukyat imkanur criteria formulated by the IICP include three criteria.[13]

First, the criteria for the position of the moon and the sun: The minimum height difference between the moon and the sun so that the moon can be observed is 4 degrees if the azimuth difference between the moon and the sun is more than 45 degrees, if the azimuth difference is 0 degrees, a height difference of more than 10.5 degrees is needed. Second, the time difference criteria for setting: The moon is at least 40 minutes later than the sun and requires a greater time difference for areas at high latitudes, especially in winter. Third, the criteria for the age of the moon (counted from ijtima '): Hilal must be more than 16 hours old for observers in the tropics and more than 20 hours for observers at high latitudes. The IICP criteria are actually not final, it may change with more data. Criteria based on lunar age and position difference appear to be strongly influenced by moonearth distance and lunar ecliptic latitude, not just geographical factors. The record for the youngest new hilal observations can be used as evidence of weakness in the criteria for different positions and the age of the new moon. The record for the success of the youngest new hilal observations was recorded at the age of 13 hours 24 minutes of the new moon which was observed on May 5, 1989 (when the earth-moon distance is relatively the closest).

It is too hard for the Indonesian reckoning expert to follow the IICP imkanur ru'yat criteria. Yet that criterion has been widely accepted astronomically. Muhammadiyah, who argued that it had not used the imkanur ru'yat criteria because "it had not yet approved the existence of a scientific imkanur ru'yat," would have felt difficult if presented with the real scientific criteria. This is because Muhammadiyah only requires a minimum immersion time difference of 1 minute, while the IICP criteria require a time difference of 40 minutes. PERSIS has not yet decided to accept the MABIMS criteria, let alone the IICP criteria. If the IICP criteria are applied in Indonesia, they may always make a difference with the followers of the ru'yatul hilal. This happens because in general the ru'yatul hilal reports in Indonesia have a very low monthly height, below the IICP criteria.[13]

Realizing this, LAPAN Bandung as an institution for research and utilization of space systematically reviews the data on hilal observations in Indonesia to obtain the criteria for a typical Indonesian rukyat imager. The complete documentation carried out by the Indonesian Ministry of Religion makes it possible to carry out the astronomical analysis needed to sort out astronomically convincing new moon observations and those suspected to contain observational errors. These criteria are expected to be input for the Ministry of Religion of the Republic of Indonesia and other Islamic organizations to determine the criteria for rukyat imkanur which are indispensable in making decisions on determining the start of Ramadan and holidays.

The data on hilal observations were taken from a collection of decrees from the Minister of Religion regarding the determination of the date of 1 Ramadan and 1 Syawal 1381-1418 H / 1962-1997 AD There were 38 observations of hilal which were reported in that time interval. The data on hilal observations that were analyzed were the date of observation, the number of observation locations and the number of observers, as well as the time of observation. The data was then confirmed with astronomical data on the sightings of the moon and the planets Venus and Mercury at sunset

In general, moon-sun height differences of less than 3 degrees (hilal height less than 2 degrees) are only reported from 1 or 2 observation locations. This could indicate that reports of rukyatul hilal with low hilal altitudes may be caused by observation errors, namely considering bright objects that are not actually hilal as hilal. These bright objects can be foreground objects on earth (eg clouds, distant lights, distant aircraft moving in the same direction as the view so that they appear to be moving only slowly downward) or background objects in the sky (especially from the planets Venus or Mercury which are close to their position. month).

To reduce the effect of this observation error, a preliminary analysis was carried out to sort the data based on the following criteria: If the moon-sun height difference is less than 4 degrees (the minimum height difference criterion according to the IICP), it must be supported by the results of observations carried out by an independent observer team at three locations or more. In addition, the minimum observational data must be supported by a complete report of the time of observation so that it can be verified based on a comparison with the moon's setting time. When all his observation time, it turns out that after the time the moon sets, the data is not used. With this main criterion, the number of data is reduced from 38 to 15 data. Astronomical disturbances from the bright enough planets Venus or Mercury can fool observers. To minimize the possibility of observational errors, additional criteria are made: If at the time of observation there is a planet Mercury or Venus which is bright enough close to the position of the moon, then this data is also not used. Then the final data analyzed then totaled 11 data ( 5 early observations of Ramadan and 6 early observations of Shawwal).[13]

The results of the analysis by filtering the data resulted in the criteria of a typical Indonesian imkanur ru'yat: First, the minimum age of the hilal was 8 hours. Second, the minimum angular distance between the moon and the sun is 5.6 degrees. Third, the minimum height difference between the moon and the sun depends on the different azimuth. For azimuth, the difference is about 6 degrees, the minimum height of the moon-sun is 
3 degrees (hilal height is about 2 degrees). If the azimuth difference is less than 6 degrees, a greater height difference is needed. For azimuthal difference of 0 degrees, the minimum height difference is 9 degrees (hilal height is about 8 degrees).

The criteria for a typical Indonesian rukyat imkanur are close to the IICP criteria and other international criteria. The criteria for a height difference of 8 degrees for azimuth difference of 0 degrees is the same as the IICP criteria if it accommodates the youngest hilal observations with a height of about 8 degrees.

Minimum altitude data comes from observations on September 16, 1974 which states that the difference in height is 3.02 degrees, azimuth difference is 6.03 degrees, moon-sun angle distance is 6.75 degrees, and hilal age is 8.08 hours and there is a time difference between sunset and moon 8 minute. The distance from the moon-sun angle of 6.75 degrees is close to the Danjon limit (7 degrees) which is a criterion supported by theoretical reasons.

The theoretical reason for the Danjon limit states that the moon cannot appear if the angular distance between the moon and the sun is less than 7 degrees due to the limited sensitivity of the average human eye. The more towards the sickle horn, the light of the hilal gets fainter. With the average sensitivity of the human eye at 8 magnitudes (scale of relative brightness of celestial bodies), at a distance of the moon about 7 - 8 degrees the hilal only appears as a point of light that does not show a crescent shape at all. This theoretical study can also be concluded that if there is an observer who is very sensitive to his eyes, he might be able to see the moonlight with a distance of less than 7 degrees from the moon-sun angle.

The minimum moon-sun angle distance comes from the observation of the new moon on August 4, 1978. Data for the new moon at that time were 4.1 degrees of moonsun azimuth difference, a height difference of 3.9 degrees, the moon-sun distance was 5.6 degrees, and the age of the new moon. 9 hours, and a 13 minute sun-moon setting. Further astronomical analysis also found no bright stars nearby. This hilal was witnessed by 11 people in 4 locations that were far apart so that it is unlikely that all witnesses could mistake the same foreground object which was considered as hilal. Astronomically, these observations can possibly be explained from theoretical studies which state the possibility of observations of the moon where the angle of the moon-sun is less than 7 degrees if the observer's eye is very sensitive. It might happen.

The IICP criteria are based entirely on empirical evidence from observations in some places in the world. Observations in Indonesia should also be used to refine criteria in the tropics. The documentation of the Indonesian Ministry of Religion is relatively very complete, revealing observations of hilal in Indonesia. This data cannot be ruled out, unless there is a scientific reason as stated in the main criteria and additional criteria for sorting data. Moreover, these observations are supported by an oath on the correctness of the observations made. There is no other means of confirmation that can prove or refute observations of the new moon, apart from eliminating the impossibility factors based on accurate astronomical analysis (among others, the moon is below the horizon at maghrib, observations made after the time of the moon has set, strong suspicion of object interference non-hilal, and the position of the hilal relative to the point of setting of the sun). It is impossible to describe the shape of the hilal for very young hilal, because it could be just a point of light without horns.

With the criteria for imkanur ru'yat from LAPAN, the criteria for the Ministry of Religion of the Republic of Indonesia are refined in two ways: First, the angle distance between the moon and the sun was originally a minimum of 3 degrees to 5.6 degrees. Second, the minimum height of the hilal is no longer uniform 2 degrees, but must pay attention to the difference in the moon-sun azimuth. The minimum height is 2 degrees if the azimuth difference is more than 6 degrees, while for the azimuth difference less than 6 degrees the minimum height is between 2 - 8 degrees.

With the criteria for imkanur ru'yat (including the applicable Ministry of Religion criteria) Eid al-Adha 1421 should have fallen on March 6, 2001. This is because the ijtima 'on February 23, 2001 occurred at 15:23 WIB. So that at maghrib February 23, 2001, in Indonesia the age of the new moon was less than 8 hours, it did not make ru'yat. Imkanur rukyat only on February 24, 2001. So that the beginning of Dzulhijjah fell on February 25, 2001 and Eid al-Adha on March 6, 2001.

\subsection{Application of MABIMS Criteria in Determining the Beginning of the Islamic Month in Brunei Darussalam.}

Hilal (child of the month) determines the beginning of Shawwal and the beginning of the month in other Qamari calendars. This is based on the word of Allah SWT [14] Meaning: They ask you about the crescent moon. Say: "The crescent moon is a sign of the time for mankind and (for worship) the pilgrimage; And it is not virtue that enters the houses from behind it, but virtue is the virtue of the godly. the door; and fear Allah that you will be lucky.

The determination of the beginning of the month for the beginning of the fasting month and the holidays is traditionally shown by the sunnah of the Prophet Muhammad, namely by merukyah hilal. This guideline has been explained in several hadiths which basically state that if Muslims want to determine the beginning of the month of Ramadan, they should perform the rukyatul hilal as the basis for determining it. Hadeeth referred to is:[15]

Meaning: You fast because you saw the hilal and break your fast because you saw the hilal. If the hilal is 
closed on you, then complete the number of Sha'ban thirty days.

Based on the hadith above, it can be seen that the beginning of determining the beginning of the month of Ramadan and Syawal must be the rukyatul hilal method. Rukyah from the language point of view means vision. From the meaning of the term, rukyah is seeing the hilal (child of the moon) after the sun sets at the end of a Hijri month for the purpose of determining the beginning of the month. In addition, the hilal may also be based on the hisab method. Hisab in terms of language means calculations or estimates. The definition of reckoning from the point of view of the term is the use of quantitative methods to calculate and predict the position of the hilal (moon) rationally. This hisab method is based on the hadith of the Prophet SAW which was narrated from Abdullah bin Umar R.A. which reads: [16]

Meaning: Do fasting because you see it (month of Ramadan) and you are open for (Eid days) because you see it (month of Shawwal). If he is protected (cannot be seen due to clouds), then let you estimate (faqduru) for it.

According to Mohammad Ilyas, in the concept of rukyah and hisab, there are at least three methods of determining the initial Syawal. First, seeing hilal (moon children) in rukyat, second, seeing hilal (moon children) based on astronomy, namely hisab, third, seeing hilal (moon children) based on physic-astronomy (Rukyah and Hisab). For those who use only rukyah as the principle of determining the beginning of the month of Shawwal, if the month is not successful, then the beginning of the month is done by perfecting the current month to 30 (thirty) days. If using the reckoning method alone, the determination is very dependent on the results of the aid of astronomical data that predict the predicted visible date of the new moon. Methods of Hisab and Rukyah can be used simultaneously, if the position of the month has met the appearance criteria (imkan al-rukyah criteria) and the month is not successful in being rukyah, then the beginning of the month is determined based on hisab.

At that time, the initial determination of Shawwal throughout the world was based on the three methods discussed earlier, namely, first, the rukyah method solely as practiced by the Arab countries and Brunei. Second, the method of reckoning falak is solely as practiced by the United States, Australia and Singapore. Third, the Rukyah and Hisab methods as practiced by Malaysia and Indonesia.

The establishment and determination of the State of Brunei Darussalam in determining the start of the month of worship such as Ramadan and Shawwal is by using the rukyah method. This rukyah hilal is performed on 29 months after sunset. If the hilal fails to be seen, the month count needs to be fulfilled to be 30 (thirty) days. In this case, the reckoning method is only used as an approximate guide, it is not used to determine the beginning of the month even though the position of the month has met the criteria for imkan al-rukyah.
According to Awang Haji Hassan Haji Metali and Awang Haji Julaihi Haji Lamat, the arguments used in the use of the rukyah method in Brunei Darussalam are as follows:

First: the Word of Allah SWT which means: [17]

Meaning: (The specified number of days is) the month of Ramadan, the month in which the Al Quran was revealed as a guide for humans and explanations of that guidance and differentiation (between the right and the false). Therefore, whoever among you is present (in the country where he lives) in that month, then let him fast in that month, and whoever is sick or on the way (then he breaks the fast), then (it is obligatory for him to fast), as many days as he has left., on other days. Allah wants convenience for you, and does not want trouble for you. And you must fill up your number, and let God give you glory for his instructions, so that you may be grateful.

Second: The hadith of the Prophet SAW that reads: [18] "It was narrated from Abdullah bin Dinar ra that Rasulullah SAW said which meant: "The month is 29 nights, (by that) then don't fast so that you see it (that month), if it is protected (by clouds) then you should perfect it. (that month) to 30 (days)". According to Awang Haji Hassan Haji Metali, based on the arguments of the Qur'an and the above Hadith, YDP Dato Seri Maharaja Dato Seri Utama Haji Awang Ismail bin Omar Abd Aziz, Mufti of Brunei Darussalam stated as follows: [19]

There are too many hadiths regarding starting fasting and breaking the fast (feast days), so that the hadiths explain that Allah depends on fasting and breaking the fast on seeing the moon child, not depending on the moon child, or on the science of reckoning, or falak, is prevented from preceding the month, fasting before seeing the lunar month, being prevented from invading the fasting month everywhere by not seeing the moon or not completing the number of 30 days, being prevented from breaking the fast before seeing the child of the month of Shawwal, or completing the number of the month of Ramadan for 30 days, this is qawl (view) which is true so that al-Imam Ibn Hajar ra said: Because the hadiths are true and valid and many of them are based on fasting and breaking with the condition that they see the child of the moon or perfect the number of months of 30 days, there is no obligation to follow al-Imam Ahmad.

Based on the arguments of the Koran, the hadith and fatwa of YDP Dato Seri Maharaja Dato Seri Utama Haji Awang Ismail bin Omar Abd Aziz clearly shows that the State of Brunei Darussalam upholds the opinion of the Shafi'iy Mazhab, where the initial determination of Shawwal can only be done if hilal can be seen with naked eye This case was later strengthened by the results of deliberations at the 4th unofficial meeting of the Ministers of Religion of Brunei Darussalam, Republic of Indonesia, Malaysia and the Republic of Singapore (MABIMS) which was held in Brunei Darussalam on 67 August 1993 in Bandar Seri Begawan. The meeting resulted in a Guideline for the Rukyah Hisab of Brunei Darussalam, Indonesia, Malaysia and Singapore. The 
decisions in the implementation of rukyah are: In addition to reckoning, rukyah is carried out to determine the beginning of the month of Ramadan, Syawal and Dzulhijjah with the following notes: The initial rukyah of Dzulhijjah is carried out to align the results of the reckoning, not to determine the entry of the beginning of the month, except for the State of Brunei Darussalam. Indonesia, Malaysia and Singapore have agreed, if the position of the moon has met the criteria for imkan alrukyah, the above and the month is not successful in being rukyah, then the beginning of the month is determined based on hisab; while for the State of Brunei Darussalam, the beginning of the month is done by observing the current month for 30 (thirty) days.

The criteria for imkan al-rukyah for MABIMS countries are as follows. First, the hilal is at an altitude of not less than 2 degrees on the western horizon when the sun sets. Second, the curvature of the hilal to the sun when the sun sets is not less than (three) 3 degrees, or the age of the hilal when the moon sets on the day of rukyah is not less than (eight) 8 hours after the ijtimak is enforced. Brunei Darussalam has implemented the determination for the beginning of the Hijri month for the months of Ramadan, Syawal and Zulhijjah by sight / perception or rukyatul hilal / child months. As for the determination of the beginning of another Hijri month is based on the estimation of the reckoning as set out in the calendar forecast for each year by referring to the method set out in the Guidelines for Hisab Rukyah Negara Brunei Darussalam, Indonesia, Malaysia and Singapore.[20] Better known as the MABIMS criteria.

The law relating to sighting of the new moon is under the authority of the Sharia Court as set out in Article 184 of the Sharia Court Deed which reads:

(1) It shall be the responsibility of the Chief Syar'ie Judge on or about the beginning, or end of each month to make an investigation to determine the day of the new months may occur rukyah, and also to make an investigation on any particular day of the new moon it can be seen and then convict and confirm the result of the rukyah with his signature.

(2) After making the investigations mentioned in subsection (1), the Chief Syar'ie Judge shall notify the conviction and confirmation of the rukyah immediately to the Yang Di-Pertua Majlis so that the matter is presented before His Majesty Paduka Seri His Majesty the Sultan and Yang Di-Pertuan of Brunei Darussalam.
The stipulations and ratifications that have been made by the Chief Judge Syar'ie regarding rukyah are muktamad (permanent legal force). This provision sets out the duties and responsibilities required by the Chief Justice of the Syar'ie Supreme Court in relation to the vision, punishment and verification of the month. And in the investigation of Supreme Court Justice Syar'ie, there are procedures that must be followed as prescribed. When the Chief Justice of the Syar'ie Supreme Court has confirmed and ratified the results of the rukyah with his signature, the Chairman of Syar'ie will announce the ratification and ratification of the rukyah to the President of the Islamic Religious Council for the issues to be presented before the Supreme Council His Excellency Sultan and His Excellency Brunei Darussalam.

At that time, the officers assigned to carry out the vision/absorption of the moon during the months of Ramadan, Shawwal and Zulhijjah were: 1) 1. Syar'ie Judges and officers from the Syariah Court; 2) Officers from the Survey Department, Ministry of Development; 3) Officers from the Ministry of Religious Affairs; 4) Officers from the Government Mufti Department, Prime Minister's Department; 5) Officers from several relevant government departments such as the Meteorological Department.

In 2003 at the same time as $1424 \mathrm{H}$, the Brunei Islamic Religion Council agreed to no longer continue the practice of receiving rukyah results from areas that were in agreement with the Brunei Darussalam State from Indonesia and Malaysia. The Brunei Islamic Religious Council has decided to determine the start of the month for the months of Ramadan, Shawwal and Zulhijjah by means of the rukyah method.

The testimony received for use in determining the start of the month of Ramadan is a witness, whereas for the month of Shawwal there are two (2) witnesses. There is no explanation for the use of this different number of sanctions at the Brunei Darussalam Syar'ie Court. The procedure for determining the beginning of the Islamic month in Brunei is as follows :[20] a) Appoint Syar'ie Judges and Officers involved such as Officers from the Ministry of Religion, Survey Department, Ministry of Development, Government Mufti Department, Prime Minister's Department to work in rukyah location; b) The Chief Syar'ie Judge along with several officers of the Syariah Court will be at the Office of the President of the Islamic Religious Council as the center for receiving reports from all rukyah places; c) The Syar'ie Judge is appointed as the trustee of the delegation to inspect

Table 1. Rukyatul Hilal Places in Brunei Darussalam

\begin{tabular}{l|l|l}
\hline No & \multicolumn{1}{|c}{ Region } & \multicolumn{1}{c}{ Location of al-Rukyah } \\
\hline 1 & Brunei Muara Region & a. Menara dst, Bangunan Ibu Pejabat dst, Lebuh Raya Tungku \\
& & b. Tanjung Batu, Kampung Sabun, Mukim Serasa \\
& Tutong area & d. Bukit agok, Kampung Jerudong, Mukim Sengkurong \\
\hline 2 & Belait area & e. Bukit Ambog, Daerah Tutong \\
\hline 3 & Bumut, Daerah Belait \\
\hline
\end{tabular}


anyone who claims to see the moon and when the time runs out to see the moon, the Syar'ie Judge will report the results of the investigation to the location to the Registrar.

The Registrar General will report all the rukyah results to the Chief Syar'ie Judge to be determined and confirmed. The Chief Syar'ie Judge will announce the determination and confirmation of the rukyah immediately to the Yang Di-Pertua of the Islamic Religious Council so that the matter is presented before the Council of His Majesty the Sultan and Yang DiPertuan of Brunei Darussalam. After the permission of His Majesty the Sultan and Yang Di-Pertuan of Brunei Darussalam, an announcement will be made live via Radio and Brunei television by the Honorable Judge of the Syariah High Court.

In the implementation of the rukyatul hilal, it does not only involve the Religious Council and the Sharia Court, but also the Ministry of Development, the Division of the Astronomy Division which has the Duties and Functions in the implementation of rukyat reckoning: 1) Make work to determine the Qibla Hala; 2) Doing rukyah for determine Early Hijrah Month: 3) Make an estimate of the time of prayer and takwim hijrah; 4) Make observations of natural phenomena (Sky watching) Lunar eclipse, sun, meteor shower, planet trajectory, supermoon etc. Data on the results of rukyah conducted in Brunei Darussalam for the last two years [19] showed that the success rate for seeing the new moon or moon children is very small, so the implementation of Ramadan fasting is more often carried out for 30 days even though it refers to the implementation of fasting by the Prophet Muhammad is often carried out for 29 days.

\section{OVERVIEW FALAK SCIENCE OR ASTRONOMY}

In the hisab method, there are many criteria put forward by hisab experts related to the change in the beginning of this Islamic month, some use the criteria of ijtima 'qabl al-ghurub (the occurrence of ijtima or conjunction before sunset), form al-hilal and imkan rukyat. The criteria for imkan al-rukyat itself also have many opinions in it. The criteria for the visibility of the new moon vary in parameters. Some are based on the height of the new moon, the moon-sun distance, the age of the new moon, the width of the crescent, or the moonsun time difference. There are simple research based only some observational evidence. Some are based on a comprehensive analysis of certain compilations of data. [21]

The Government of the Republic of Indonesia, in this case is the Ministry of Religion through BHR, used hisab imkan al-ru'yah (calculations and the possibility of the hilal can be seen). The hisab used is to consider the data on the appearance of the hilal that is collected and the criteria are set. Hisab is necessary because in order to carry out the rukyat command, the scholars do hisab first, to find out how high the hilal is at the time of ijtima '(conjunction).
It's just that there is no agreement on the criteria for imkan al-ru'yah. The imkan al-ru'yah criteria is a criterion in determining the beginning of the Islamic month, whose existence is considered an attempt to bridge the between hisab and rukyat. This criterion is used by the government in determining the beginning of the Islamic month and appears in the established standard Hijri calendar, which was originally the result of the Consultation of the Ministers of Religion of Southeast Asian countries, namely Brunei Darussalam, Indonesia, Malaysia and Singapore (MABIMS), so that this criterion is more known as the MABIMS criterion. Initially, the MABIMS version of rukyat criteria only agreed on irtifa 'hilal (the height of the hilal from Ufuq), which is at least two (2) degrees above ufuq.

The Ministry of Religion of the Republic of Indonesia, in this case the BHR (Rukyat Hisab Agency) continues to analyze contemporary computed data (hisab) for later cross-checking with data obtained from observations of hilal or rukyat hilal. Based on rukyat data from the Ministry of Religion of the Republic of Indonesia for 30 years, there have been more reports of new sightings of the new moon which can be said to meet the visibility requirements and scientific studies. So that in the end there was an agreement from various Islamic organizations and astronomical experts in Indonesia which was initiated by the Indonesian Ministry of Religion's BHR in a workshop in order to find the initial format for the Islamic month in Indonesia which was held from 19 to 21 September 2011 at the Grand USSU hotel, Bogor. Where the outcome of the workshop decision was that the Imkan Rukyat MABIMS criteria needed to be refined. The form of correction or refinement of the imkan rukyat criteria becomes the 238 criterion, which means that the irtifa 'hilal (height of the hilal) is at least two (2) degrees, the distance of the elongation of the hilal (month) from the sun is at least three (3) degrees and the age of the hilal after conjunction or ijtima 'minimum of eight (8) hours at the time of setting the sun (ghurub).[2]

As a comparison and analysis of the results of the workshop decision regarding the criteria for the initial Islamic month, the researchers describe some data related to several forms of hilal visibility criteria as the initial parameters for the Islamic month that have been put forward by experts.

Quoting what Thomas Jamaluddin said, he said:

Danjon (1932, 1936, in Schaefer, 1991) first obtained the condition of moon illumination as a prerequisite for the sight of the moon, which based on the extrapolation of observational data stated that at a moon-sun distance $<7^{\circ}$ the hilal was impossible to see. This $7^{\circ}$ limit is known as the Danjon limit. With the model, Schaefer (1991) shows that the Danjon limit is due to the sensitivity limit of the human eye which cannot see the very thin hilal light. Schaefer (1991) shows that the total brightness of the hilal crescent decreases as the moon gets closer to the sun. At a distance of $5^{\circ}$ the brightness at the center of the crescent is only 10.5 magnitude, while at the end of the crescent horn at a position of $50^{\circ}$ the brightness is only 12 
magnitude. At the limit of the sensitivity of the human eye, around magnitude 8 , the closest hilal to the sun is about $7.5^{\circ}$. At this distance only the center of the sickle is visible. For longer distances from the sun the crescent arc looks greater, for example at a distance of $10 \mathrm{o}$ the crescent arc to about $50^{\circ}$ from the center of the crescent to the tip of the crescent horn (cusps).[22]

From the information above, Danjon has its own criteria for hilal visibility, namely by considering the distance between the sun and the moon or moon, which is at least 7 degrees. With this distance, according to his observations or observations, the new hilal can be seen with the eye. The conclusion of the Danjon research results ignores the difference between the height of the new moon and the sun or zero (0). In addition to the criteria for the visibility of the Danjon new moon, there are other criteria put forward by astronomers or astronomers, including M. Ilyas, who suggests that the appearance of the new hilal can be seen with the eye is that the height difference between the new moon and the sun is not less than four (4) degrees. while the azimuth difference between the sun and the hilal or the moon is not less than ten point five (10.5) degrees [24].

The other criteria for visibility of the new moon as a comparison are those set by the IICP (International Islamic Calendar Program). Where the visibility criteria are divided into three conditions, namely first, the criteria for the position of the moon or hilal and the sun; the minimum height of the hilal that can be rukyat (imkan rukyat) is four (4) degrees with the condition that the moon-sun azimuth difference is greater than four point five (4.5) degrees, and if the azimuth difference is zero (0) degrees then a minimum hilal height is required. ten point five (10.5) degrees. Second, the criteria for the difference in setting time between the sun and the hilal so that the new moon can be observed (imkan rukyat) if the time of setting of the hilal is at least forty (40) minutes later than the time of setting the sun. Meanwhile, for areas that are at high latitudes, especially in winter, a greater difference between the sun and the new moon is required. Third, the criteria for the age of the month are calculated from ijtima '(conjunction); so that the hilal can be observed (imkan rukyat) the hilal must be more than sixteen (16) hours from the time of ijtima '(conjunction) to the setting of the sun (ghurub) by considering the position or presence of person who doing the rukyat or observer when in an area that has a tropical climate such as Indonesia, while observers who are in areas with high hilal traverses must be more than twenty (20), counting from the occurrence of ijtima '(conjunction) to the setting of the sun (ghurub) [24].

Meanwhile in Indonesia there is an opinion related to the visibility of the hilal which was put forward by Thomas Djamaluddin from LAPAN (National Institute of Aeronautics and Space). Regarding the visibility criteria for the visibility of the hilal 238 Thomas commented and criticized quite sharply, he argued that the criteria 238 need to be reviewed and corrected based on theoretical scientific facts as well as practical empirical. As he said :

"Criteria for Hisab-Rukyat Indonesia" (read; criteria 238 ) is only a refinement of the MABIMS criteria that have been used by BHR, the 20 month high criteria used by Nahdlatul Ulama (NU), the criteria for wujudul hilal with the principle of wilayatul hukmi (equivalent with the criteria for the height of the month 0o) which is used by Muhammadiyah, and the criteria for the existence of a hilal throughout Indonesia which are used by the Islamic Union (Persis). Do not let the criteria that become guidelines are based solely on the interpretation of syar'i arguments without the scientific basis of astronomy or based on the astronomically controversial old rukyat reports, so that it will only be a 'mockery' of the international astronomical community against the criteria used in Indonesia. The refinement of the "Criteria for Hisab-Rukyat Indonesia" was carried out to bring all of these criteria closer to physical computation and rukyat hilal according to astronomical studies. Thus the rukyat and hisab aspects have a strong foothold, not just a reference to syar'i propositions but also an operational interpretation based on science-astronomy that can be accepted together.

With these common criteria, reckoning and rukyat are no longer dichotomized but are considered complementary. This criterion should also be considered as a dynamic criterion that must be evaluated periodically (eg every 10 years) to accommodate the development of the latest observational data [23].

Furthermore, Thomas said the proposed criteria for new visibility in the Indonesian context were hilal height or the height difference between the hilal and the sun was more than four (4) degrees, while the difference between solar azimuth and hilal was more than six point four (6.4) degrees. In the context described by Thomas, it can be considered an observable hilal (imkan rukyat) for the Indonesian context. According to him, the proposal is a complement to the 238 criteria used by the government, in this case the BHR of the Ministry of Religion. The emergence of this proposal, according to him, was based on the comparison of the data on the criteria for the visibility of the new moon that had been presented by astronomers or astronomers - as previously described and also still accommodated the government's criteria of 238 . The point is that the proposal is a middle ground between the criteria that have been put forward by astronomers and the criteria of the government.

In researchers opinion, what Thomas conveyed should be appreciated as an effort to unify the differences in the determination of the beginning of the Islamic month in Indonesia, but on the other hand, when this proposal is implemented, according to researchers it will actually lead to gaps in the difference between hisab and rukyat in Indonesia is getting wider, and unification efforts will be increasingly difficult to materialize. So that for researchers, the decision of the government workshop regarding the criteria 238 has become a decision that should serve as a guideline for determining the beginning of the Islamic month in Indonesia and should also all Islamic organizations and Indonesian Muslims in general accept the decision. Based on the facts in the field using the 238 criteria, it is almost 
certain that there will be reports of observed hilal even though only in a few points in the territory of Indonesia.

\section{CONCLUSION}

There are two main points that can be concluded from this research. (1) Regarding to the application of the MABIMS Criteria in determining the start of the Islamic month in Indonesia and Brunei Darussalam, the two countries only apply it in other than the months of Ramadan, Shawwal, and Dzulhijjah, while the determination of the initial three months of Islam uses the guidelines of rukyatul hilal. However, Brunei Darussalam strictly regulates and decides its position in implementing the MABIMS Criteria with the provisions that have been made, namely Article 184 of the Sharia Courts Deed. Meanwhile, Indonesia in the determination of the beginning of Ramadan, Shawwal, and Dhulhijjah refers to the results of the isbat session held by the Ministry of Religion RI, where the decision for the isbat meeting is relatively more inclined towards the results of the rukyat hilal in the field. (2) In terms of the validity of the application of the MABIMS Criteria in Indonesia and Brunei Darusslam according to fiqh falaq and astronomy, it is permissible to use the observational data approach or rukyatul hilal in the field, meaning that the MABIMS Criteria in the initial determination of the Islamic month has accommodated the school of hisab and rukyatul hilal. Meanwhile, in terms of astronomy, the MABIMS criteria have met astronomical principles which are supported theoretically as well as data in the field.

\section{REFERENCES}

[1] S. Azhari, Visibilitas Hilal MABIMS dan Implementasinya, dalam Museum Astronomi Islam, Bukit Angkasa, 10 Ramadan 1433/29 Juli 2017

[2] Surat Keputusan Lokakarya Mencari Kriteria Format Awal Bulan Indonesia, tahun 2011

[3] F. Y. Yacob, F. A. Shah, "Metode Penentuan Awal Ramadhan Dan Hari Raya Menurut Ulama", Jurnal Ilmiah Islam Futura, 16(1) (2017) 9-31, DOI: http://dx.doi.org/10.22373/jiif.v16i1.741

[4] B. Iman, "Penetapan Awal Bulan Qamariyah Perspektif Fiqh", DIKTUM: Jurnal Syariah dan Hukum, 14(1) (2016) $1-28$, DOI: https://doi.org/10.35905/diktum.v14i1.220

[5] J. Jayusman, "Kajian Ilmu Falak Perbedaan Penentuan Awal Bulan Kamariah: Antara Khilafiah Dan Sains", Jurnal Ilmu Syari'ah Al-Maslahah, 11(1) (2015)

[6] M. R. Amir, "Metodologi Perumusan Awal Bulan Kamariyah Di Indonesia", ELFALAKY: Jurnal Ilmu Falak, 1(1) (2017)
[7] B. Waluyo, Penelitian Hukum dalam Praktek, Jakarta : Sinar Grafika, 2002

[8] Tim Dosen Fak. Syari'ah, Buku Pedoman penulisan karya ilmiah, Malang: Fakultas Syari'ah UIN, 2011

[9] L. J. Moleong, Metodologi Penelitian Kualitatif, Bandung: PT Remaja Rosdakarya, 2002

[10] K. Asmuni et.al., Dasar-Dasar Ilmu Falak, Makalah Diklat Hisab Rukyat di UIN Malang, Januari 2011

[11] A. Suziknan, Ilmu Falak Teori dan Praktik. Yogyakarta: Lazuardi, 2001

[12] Y. al-Qardawi, al-Hisab al-Falaky wa Ithbat Awa'il al-Shuhur, makalah diarmbil dari situs Yusuf alQardawi www.qaradawi.net

[13] T. Djamaluddin, "Kriteria Imkanur Rukyat Khas Indonesia: Titik Temu Penyatuan Hari Raya Dan Awal Ramadhan" dalam https://tdjamaluddin.wordpress.com/2010/06/22/kr iteria-imkanur-rukyat-khas-indonesia-titik-temupenyatuan-hari-raya-dan-awal-ramadhan/

[14] QS. Al-Baqarah (2) : 189

[15] M. ibn Ismail Abu Abd Allah al-Bukhariy, Sahih alBukhariy, Vol. 2 (tt: Dar Tauq al-Najah, tt), 27 Hadith nomor 1909

[16] Al-Bukhary, Shahih, Hadits Nomor 1906

[17] QS. Al-Baqarah (2) : 185

[18] M. ibn Ismail Abu Abd Allah al-Bukhariy, Sahih al-Bukhariy, vol.2 (tt: Dar Tauq al-Najah, tt), 27. Hadith nomor 1907

[19] Materi pemaparan Jabatan Ukur Brunei Darussalam hari Rabu tanggal 21 Agustus 2019 dalam Kegiatan Focus Disscussion Group (FGD) di Aula Pertenmuan Kantor Jabatan Ukur Brunei Darussalam

[20] Pemaparan Mohd Azerin bin $\mathrm{Hj}$ Mohd Jaya, Pegawai Ugama Mahkamah-Mahkamah Syariah, Jabatan Kehakiman Negara, Jabatan Perdana Menteri Brunei Darussalam pada hari Kamis tanggal 22 Agustus 2019 di ruang Pertemuan Mahkamah-Mahkamah Syariah.

[21] T. Djamaluddin, Menuju Titik Temu Hisab Wujudul Hilal dan Hisab Imkan Rukyat, dalam :https://tdjamaluddin.wordpress.com/2011/10/25/m enuju-titik-temu-hisab-wujudul-hilal-dan-hisabimkan-rukyat/ 
[23] Thomas, Analisis Visibilitas Hilal untuk Usulan Kriteria Tunggal di Indonesia, dalam https://tdjamaluddin.wordpress.com/2010/08/02/

[24] J. A. Utama, Sekilas Pengetahuan Kriteria Visibilitas Hilal, dalam http://media.isnet.org/kmi/iptek/gapai/HilalTampa k.html diakses 10 Agustus 2016 